\title{
Physicochemical and Antimicrobial Properties of Kinang Extract Microparticle on Various Time and Temperature of Ultrasonication Process
}

\author{
Inka Rizki Padya ${ }^{1}$, Gatot Priyanto ${ }^{2}$, Rindit Pambayun ${ }^{2 *}$
}

${ }^{1}$ Agroindustrial Technology Interest on Agribusiness Magister Program, Faculty of Agriculture, Sriwijaya University, Indonesia

${ }^{2}$ Department of Agricultural Technology, Faculty of Agriculture, Sriwijaya University, Jl. Palembang-Prabumulih Km 32, Ogan Ilir 30139, Indonesia

DOI: $\underline{10.36347 / \text { sjet.2020.v08i01.002 }}$

| Received: 13.12.2019 | Accepted: 23.12.2019| Published: 16.01.2020

*Corresponding author: Rindit Pambayun

Abstract Original Research Article

The research was aimed to determine the chemical and antimicrobial characteristics of the microparticle kinang extract using ultrasonication on various temperature and time ultrasonication process. This study uses a randomized factorial completely design with two treatment. The measuring parameters was consisted of chemical properties (antioxidant activity, total phenol, moisture content and $\mathrm{pH}$ value) and antimicrobial analysis (antibacterial activity). The results showed that time of ultrasonication treatment had significant effect on antioxidant activity, total phenol, antibacterial activity, moisture content and $\mathrm{pH}$ value. And temperature of ultrasonication treatment had significant effect on total phenol, antibacterial activity, moisture content and $\mathrm{pH}$ value. The interaction between time of ultrasonication and temperature of ultrasonication had significant effect on antibacterial activity, moisture content and $\mathrm{pH}$ value.

Keywords: Microparticles, kinang extract, ultrasonication.

Copyright @ 2020: This is an open-access article distributed under the terms of the Creative Commons Attribution license which permits unrestricted use, distribution, and reproduction in any medium for non-commercial use (NonCommercial, or CC-BY-NC) provided the original author and source are credited.

\section{INTRODUCTION}

Indonesia is one of the tropical countries that have biodiversity known as a warehouse for herbal plants. Many Indonesian people have a healthy habit of consuming a mixture of herbal ingredients such as kinang. Indonesian people call the term "Nginang". Nginang is usually carried out by parents and used for traditional events and is considered to strengthen teeth and inhibit caries in the teeth [1]. Nginang consists of several ingredients mixed from herbal plants such as betel leaf, areca nut, whiting and gambier which are then chewed. A material capable of holding has different benefits. In betel leaf contains $4.5 \%$ essential oil which will produce a distinctive aroma [2]. Pinang contains $15 \%$ tannin which causes betel nut to have antibacterial and antioxidant benefits [3]. Betel lime has a dry or wet form that is useful to change the acidic environment to alkaline [4]. Gambir contains $7-33 \%$ of catechin compounds which have benefits as antioxidants and as an inhibitor of the growth of Streptococcus mutans bacteria [5].

The composition of mixed ingredients in kinang have many benefits needs to be streamlined so as to increase added value. One way that can be used is by applying technology with the application of new technologies such as microparticle. The application of microparticle to kinang can make a new innovation. Microparticles are particles which have a particle size of 1-1000 $\mu \mathrm{m}$. Microparticles can release more than $80 \%$ of the active substance within 10 minutes. Microparticles are one of the delivery systems that can be administered orally, transdermal, intramuscular, intraperitoneal and lung [6].

Microparticles can be made by several methods including solvent evaporation, ionic gelation, dry spray, coacervation, and supercritical fluid extraction [7]. One method that is often used is one with the ionic gelation method. This method is carried out by mixing chitosan polymers with sodium tripolyphosphate polyanion.

Ionic gelation allows the interaction between positively charged amino groups in chitosan with negatively charged tripolyphosphate to enable the formation of modified chitosan with micrometer morphology and even nanometers. Chitosan without cross-linking at micron size has a large surface area of particles which allows greater adsorption capacity but is unstable because it is easily dissolved in water [8]. With 
Inka Rizki Padya et al., Sch J Eng Tech, Jan, 2020; 8(1): 9-13

the ionic gelation method using sodium tripolyphosphate material can produce modified chitosan products with micrometer size and are more stable [9].

The use of ionic gelation methods can be modified by the addition of ultrasonication to facilitate the formation of microparticle sizes. Ultrasonication is a method that uses samples with suitable mixing solvents and is placed into an ultrasonic bath at a certain temperature and time [10]. Ultrasonic has become an important implement for microparticle until nanoparticle synthesis. Ultrasonic is a good method for microparticle preparation with controlled morphology [11].

The application of microparticle to kinang extract using ultrasonication was expected to produce new products with better quality and can be applied to food and health products.

\section{MATERIALS AND METHODS Preparation of Kinang Extract}

All constituents of kinang were made into powder form, filtered using 40 mesh sieves. The production of kinang extract was carried out by cold maceration. The extraction process with maceration technique was done by shaking several times or stirring at room temperature [12]. All the ingredients making up the kinang were weighed according to the formulation of kinang [13] that will be used, namely betel leaf ( $8 \mathrm{~g})$, areca nut $(3.5 \mathrm{~g})$, gambier $(2.5 \mathrm{~g})$ and whiting $(2 \mathrm{~g})$. And mixed all the ingredients that had been weighed. The mixed form of kinang was put into a bottle and a water solvent is added in a ratio of 1: 10. Then shaken and soaked for 24 hours. In the first 6 hours the samples were shaken until evenly distributed and allowed to stand again for the next 18 hours. After soaking for 24 hours, the sample was filtered using filter paper. The waste obtained then remodelled again up to $2 x$. The results of the first extraction and remaresation results then mixed and stirred until evenly distributed.

\section{Preparation and Synthesis of Kinang Extract Nanoparticle Solutions}

Microparticle were made using chitosan and sodium tripolyphosphate as a coating solution for kinang extract based on the research by [14]. Making chitosan solution was by weighing as much as $0.5 \mathrm{~g}$ of chitosan using a watch glass then chitosan is dissolved with $5 \% \mathrm{v} / \mathrm{v}$ acetic acid to $100 \mathrm{~mL}$ and stirred with a magnetic stirrer for 5 minutes. And making sodium tripolyphosphate solution by weighing sodium tripolyphosphate as much as $0.2 \mathrm{~g}$ then dissolved with distilled water to $40 \mathrm{~mL}$ and stirred with a magnetic stirrer for 5 minutes.

Synthesis of microparticle kinang extract using chitosan-STPP as a coating. The steps taken were a modification of the research method by $[14,15]$. The
$100 \mathrm{~mL}$ chitosan solution was stirred with a magnetic stirrer for 10 minutes. During stirring, added $50 \mathrm{ml}$ of kinang extract gradually and after mixing it was stirred again for 15 minutes. Added $40 \mathrm{~mL}$ sodium tripolyphosphate solution and stir for 20 minutes until homogeneous. Kinang-chitosan-sodium tripolyphosphate mixture solution was sonicated to help breakdown the particles contained in the solution using two treatments (temperature and time).

\section{Ultrasonication Treatment}

The microparticles solution of kinang extract which was ready then carried out the next process by using the aid of ultrasonic water bath type [16]. The preparation of ultrasonication equipment, the sonication device used is the Elmasonic S $60 \mathrm{H}$ sonicator type cleaning sonicator (water bath) with a frequency of 35 $\mathrm{kHz}$. Before using this sonicator, first add enough water as a medium for propagation of ultrasonic sound energy to the sample. A sample solution was placed into the sonicator as much as 1 liter for each treatment. The temperature and time of the instrument was set according to the treatment, the treatment time used is 30 minutes, 60 minutes, 90 minutes and 120 minutes, while the temperature used was $50^{\circ} \mathrm{C}, 60^{\circ} \mathrm{C}$ and $70^{\circ}$ $\mathrm{C}$ with three replications per treatment. After the sample solution had been carried out the ultrasonication process, then dried in the sample solution using a freeze drying (capacity of 5 liters). The solution of the dried sample was then smoothed using a softener.

\section{Design of Experiment}

Experiment was conducted on completely randomized factorial design, with two treatment, namely time ultrasonication treatment and temperature ultrasonication treatment. The time ultrasonication treatment was consisted of four level, namely 30 minutes (coded by N1), 60 minutes (coded by N2), 90 minutes (coded by N3), and 120 minutes (coded by N4). The sonication temperature treatment was consisted of three level treatment, namely $50^{\circ} \mathrm{C}, 60^{\circ} \mathrm{C}$ and $70^{\circ} \mathrm{C}$ (respectively coded by $\mathrm{T} 1, \mathrm{~T} 2$, and $\mathrm{T} 3$ ).

\section{The Physicochemical and Antimicrobial Analysis}

The physicochemical analysis of microparticle kinang extract was consisted of antioxidant activity [17], total phenol content [18], moisture content [17] and $\mathrm{pH}$ value [19]. The antimicrobial analysis of microparticle kinang extract was consisted of antibacterial activity [20].

\section{RESULTS}

The values of antioxidant activity, total phenol content, moisture content, $\mathrm{pH}$ value, antibacterial activity of microparticle kinang extract was shown in Table-1. Results of analysis of variance showed that $\mathrm{N}$ factor (time ultrasonication), $\mathrm{T}$ factor (temperature ultrasonication) and their interactions had not significant effect on antioxidant activity, total phenol content, moisture content, and $\mathrm{pH}$ value. 
Table-1: Antioxidant activity, total phenol content, moisture content, pH value, and antibacterial activity of microparticle kinang extract

\begin{tabular}{|l|l|l|l|l|l|}
\hline Treatment & Antioxidant activity & Total phenol content & Moisture content & pH value & Antibacterial activity \\
\hline $\mathrm{N}_{1} \mathrm{~T}_{1}$ & $240.94 \pm 80.94^{\mathrm{a}}$ & $147.92 \pm 4.88^{\mathrm{bcd}}$ & $3.32 \pm 0.06^{\mathrm{a}}$ & $4.78 \pm 0.29^{\mathrm{c}}$ & $7.81 \pm 1.01^{\mathrm{a}}$ \\
\hline $\mathrm{N}_{2} \mathrm{~T}_{1}$ & $142.66 \pm 6.08^{\mathrm{bcd}}$ & $169.10 \pm 14.10^{\mathrm{abcd}}$ & $2.44 \pm 0.13^{\mathrm{bc}}$ & $5.00 \pm 0.19^{\mathrm{bc}}$ & $5.42 \pm 0.10^{\mathrm{bc}}$ \\
\hline $\mathrm{N}_{3} \mathrm{~T}_{1}$ & $113.62 \pm 7.45^{\mathrm{bcd}}$ & $201.18 \pm 6.58^{\mathrm{a}}$ & $2.16 \pm 0.11^{\mathrm{c}}$ & $5.06 \pm 0.13^{\mathrm{bc}}$ & $6.05 \pm 0.23^{\mathrm{bc}}$ \\
\hline $\mathrm{N}_{4} \mathrm{~T}_{1}$ & $101.84 \pm 18.42^{\mathrm{cd}}$ & $203.29 \pm 7.73^{\mathrm{a}}$ & $1.70 \pm 0.14^{\mathrm{d}}$ & $5.19 \pm 0.06^{\mathrm{bc}}$ & $5.55 \pm 0.28^{\mathrm{bc}}$ \\
\hline $\mathrm{N}_{1} \mathrm{~T}_{2}$ & $194.46 \pm 38.31^{\mathrm{abc}}$ & $120.47 \pm 1.15^{\mathrm{d}}$ & $3.49 \pm 0.12^{\mathrm{a}}$ & $4.81 \pm 0.31^{\mathrm{bc}}$ & $6.44 \pm 0.08^{\mathrm{b}}$ \\
\hline $\mathrm{N}_{2} \mathrm{~T}_{2}$ & $143.57 \pm 43.62^{\mathrm{bcd}}$ & $128.25 \pm 18.18^{\mathrm{cd}}$ & $2.65 \pm 0.22^{\mathrm{b}}$ & $5.18 \pm 0.14^{\mathrm{bc}}$ & $5.37 \pm 0.15^{\mathrm{c}}$ \\
\hline $\mathrm{N}_{3} \mathrm{~T}_{2}$ & $96.64 \pm 20.34^{\mathrm{d}}$ & $138.74 \pm 11.42^{\mathrm{cd}}$ & $1.72 \pm 0.23^{\mathrm{d}}$ & $5.19 \pm 0.12^{\mathrm{bc}}$ & $5.25 \pm 0.10^{\mathrm{c}}$ \\
\hline $\mathrm{N}_{4} \mathrm{~T}_{2}$ & $92.10 \pm 6.79^{\mathrm{d}}$ & $170.22 \pm 14.92^{\mathrm{abcd}}$ & $1.32 \pm 0.06^{\mathrm{e}}$ & $5.31 \pm 0.06^{\mathrm{b}}$ & $5.21 \pm 0.13^{\mathrm{c}}$ \\
\hline $\mathrm{N}_{1} \mathrm{~T}_{3}$ & $205.68 \pm 34.42^{\mathrm{ab}}$ & $156.77 \pm 23.11^{\mathrm{abcd}}$ & $3.40 \pm 0.10^{\mathrm{a}}$ & $5.14 \pm 0.09^{\mathrm{bc}}$ & $5.80 \pm 0.28^{\mathrm{bc}}$ \\
\hline $\mathrm{N}_{2} \mathrm{~T}_{3}$ & $98.70 \pm 17.09^{\mathrm{d}}$ & $164.14 \pm 16.89^{\mathrm{bccd}}$ & $2.66 \pm 0.08^{\mathrm{b}}$ & $5.26 \pm 0.19^{\mathrm{bc}}$ & $5.62 \pm 0.33^{\mathrm{bc}}$ \\
\hline $\mathrm{N}_{3} \mathrm{~T}_{3}$ & $92.65 \pm 6.66^{\mathrm{d}}$ & $180.51 \pm 44.12^{\mathrm{abc}}$ & $1.50 \pm 0.04^{\mathrm{de}}$ & $5.85 \pm 0.20^{\mathrm{a}}$ & $5.15 \pm 0.13^{\mathrm{c}}$ \\
\hline $\mathrm{N}_{4} \mathrm{~T}_{3}$ & $82.15 \pm 12.26^{\mathrm{d}}$ & $192.69 \pm 4.28^{\mathrm{ab}}$ & $1.27 \pm 0.10^{\mathrm{e}}$ & $6.25 \pm 0.09^{\mathrm{a}}$ & $5.08 \pm 0.18^{\mathrm{c}}$ \\
\hline
\end{tabular}

Note: values followed by the different letter was significantly different, according to Tukey's at the probably level of $5 \%$

\section{DISCUSSIONS}

Antioxidant activity of microparticle using ultrasonication had $\mathrm{IC}_{50}$ values ranging from $82.15 \mathrm{ppm}$ to $240.94 \mathrm{ppm}$. The higest antioxidant activity was found in the treatment sonication time of 120 minutes and sonication temperature of $70^{\circ} \mathrm{C}$ was $82.15 \mathrm{ppm}$ and the lowest antioxidant activity was found in the treatment of sonication time of 30 minutes and sonication temperature of $50^{\circ} \mathrm{C}$ which was $240.94 \mathrm{ppm}$. $\mathrm{IC}_{50}$ value was defined as the magnitude of the concentration of the test compound that can reduce free radicals by as much as $50 \%$. The smaller the $\mathrm{IC}_{50}$ value, the higher the free radical scavenging activity [21]. Antioxidant activity produced microparticle kinang extract using time and temperature variations in the ultrasonication process was included in the category of moderate to strong antioxidants activity. This was due to the long duration of ultrasonication that will multiply cells that break, so that the antioxidant compounds in the kinang will come out. The sonication process was an exothermic process which generates heat and can create interface movements between solid and liquid, thereby causing an increase in mass transfer rate and increasing product yield [22].

Total phenol levels had a relationship with antioxidant activity. This phenolic compound was widely distributed in plants and had been reported to have antioxidant activity. In addition, polyphenols have hydroxyl groups in different amounts and positions that can function as antibacterial compounds [23]. The total phenol content produced showed that the longer the sonication process, the higher the total phenol produced. This was because the cavitation waves generated during sonication can make the cells in the kinang extract split so that the phenol compound can be easily extracted out and then absorbed with a solution of chitosan-stpp microparticles. The principle of ultrasonic extraction was to increase mass transfer caused by increased solvent penetration into plant tissue through the capillary effect. Cavitation bubbles formed on the cell walls of plants due to ultrasonic waves. The effect of bursting cavitation bubbles resulted in an increase in pores in the cell wall. Cavitation bubbles splited due to the thinness of the glandular parts of plant cells which can be easily damaged by sonication [24].

Analysis of antibacterial activity using Streptococcus mutans in this study aims to determine the activity of flavonoids namely catechins and tannins contained in the mixture of kinang powder which acts as an antibacterial and anti-inflammatory. Classification responses of bacterial growth inhibition power seen based on clear zone diameter consists of 4 groups: weak response (diameter $<5 \mathrm{~mm}$ ), moderate (diameter 5-10 $\mathrm{mm}$ ), strong (diameter 10-20 $\mathrm{mm}$ ), and very strong (diameter $<20 \mathrm{~mm}$ ) [25]. The antibacterial activity of kinang extract microparticle using ultrasonication has an average value of inhibition diameter of Streptococcus mutans ranging from $0.33 \mathrm{~mm}$ to 3.06 $\mathrm{mm}$ by using paper discs with a diameter of $4.75 \mathrm{~mm}$. This was because the duration of sonication can reduce the antibacterial activity found in the microparticle solution.

The lowest moisture content value was found in treatment sonication time 120 minutes and sonication temperature $70{ }^{\circ} \mathrm{C}$ while the highest water content value was found in treatment sonication time 30 minutes and sonication temperature $60{ }^{\circ} \mathrm{C}$. Moisture content of microparticles of kinang extract shows that the longer the ultrasonication process and the higher the ultrasonication process temperature, the lower the value of the water content produced. This was due to the long sonication process which was able to break down particles in solution into smaller particles so that after drying using freeze drying it will produce a low water content value.

Based on the degree of acidity, a food can be classified into three groups of degrees of acidity, namely the first low-acidity food with a $\mathrm{pH}$ range of 5.3 to 4.5 , the second medium-acidity food with a $\mathrm{pH}$ range of 4.5 to 3.7 and the last was high-acidity food with a $\mathrm{pH}$ below 3.7 [26]. The resulting $\mathrm{pH}$ value indicated the 
longer the ultrasonication process and the higher the temperature used, then the $\mathrm{pH}$ value produced increases. This was because the ultrasonication process with variations in time and temperature increases the $\mathrm{pH}$ value produced due to the amount of amine ions that will be protonated [27].

\section{CONCLUSIONS}

The chemical and antimicrobial changes had occurred on microparticles of kinang extract with various time and temperature ultrasonication process. The interaction between time of ultrasonication and temperature of ultrasonication had significant effect on antibacterial activity, moisture content and $\mathrm{pH}$ value.

\section{ACKNOWLEDGMENTS}

This research was supported by research and publication through Hibah Profesi Grant of LPPM Sriwijaya University. We thank our colleagues from Sriwijaya University, South Sumatera, Indonesia who provided insight and expertise that greatly assisted the research.

\section{REFERENCES}

1. Gandhi G, Kaur R, and Sharma S. Chewing Pan Masala and Betel Quid-Fasionable Attributes and Cancer Menaces. Journal of Human Ecology; 2005; 17(3): 161-166.

2. Rosman R, and Suhirman. Betel Medicinal Plants that Need to Get a Touch of Cultural Technology. Warta Penelitian dan Pengembangan Tanaman Industri; 2016; 12(1): 13-15.

3. Harnowo I, and Yunianta. Addition of Areca Seed Extract and Citric Acid on Physical, Chemical and Organoleptic Properties of Star Fruit Extract; Jurnal Pangan dan Agroindustri; 2015; 3(3): 12411251.

4. Dwi WAF. Management of Apexification: in Upper Front Fracture due to Trauma. Indonesian Journal of Dentistry; 2007; 14(3): 199-203.

5. Pambayun R, Gardjito M, Sudarmadji S, and Kuswanto KR. Sensitivity of Positive Gram Bacteria to Catechins Extracted from Gambir (Uncaria gambir Roxb). Agritech; 2008; 28(4): 175-179.

6. Parida K, Panda S, Ravanan P, Roy H, Manickam M, and Talwar P. Microparticles Based Drug Delivery Systes: Preparation and Application in Cancer Therapeutics. International Archieve of Applied Science and Technology; 2013; 4(3): 6875.

7. Muhaimin. Study of Microparticle Preparation By The Solvent Evaporation Method Using Focused Beam Reflectance Measurement (FBRM). University Berlin, United Stated. 2013.

8. Tao Yi, Zhang HL, Hu YM, Wan, Shuo, and Su ZQ. Preparation of Chitosan and Water-Soluble Chitosan Microspheres Via Spray-Drying Method to Lower Blood Lipids in Rats Fed with High-Fat
Diets. International Journal of Moleculer Science, 2013; 14: 4174-4184.

9. Sivakami MS, Gomathi T, Venkatesan J, Jeong HS, Kim SK, and Sudha PN. Preparation and characterization of nano chitosan for treatment wastewaters. International Journal of Biological Macromelecules; 2013; 57:204-212

10. Klejdus B, Kopecky J, Benesova L, and Vacek J. Solid-Phase/Supercritical-Fluid Extraction for Liquid Chromatography of Phenolic Compounds in Freshwater Microalgae and Selected Cyanobacterial species. Journal Chrom. Advance; 2009; 12(16): 763-771.

11. Rane AV, Kanny K, Abhita VK, and Thomas S. Synthesis of Inorganic Nanomaterials, Book Chapter 5: Method for Synthesis of Nanoparticle and Fabrication of Nanocomposites. 2018; 121139.

12. Depkes Republik Indonesia. Standard Parameters of Medicinal Plant Extracts. 2000; Jakarta: Departemen Kesehatan Republik Indonesia.

13. Verawati E. Functional Marshmallow with the Addition of Cheweing Betel Extract. Universitas Sriwijaya, South Sumatera. 2017; 28 48.

14. Pakki E, Sumarheni, Aisyah F, Ismail, and Safirahidzni S. Formulation of Nanoparticle Dayak Onion (Eleutherine americana (Aubl) Merr) Extract with Variation of ChitosanTripolyphosphate (TPP) Concentration Variation. J. Trop. Pharm. Chem; 2016; 3(4):251-263.

15. Wahyudi CT, Wijayanti SD, and Harijono. The Effect of Concentration Coating Medium and Long Ultrasonication on Particle Size and Antioxidant Activity of Solo Garlic Nano Extract. Jurnal Pangan dan Agroindustri; 2018; 6(3): 8-17.

16. Hielscher T. Ultrasonic Production of Nano-Size Dispersions and Emulsions, dalam: Proceedings of European Nanosystems Conference ENS'05; 2005.

17. AOAC. 2005. Official Methods of Analysis. (17 edn). Association of Official Analytical Chemist. Benyamin Frangklin Station. Washington DC.

18. Septiana TA, Muchtadi D, and Zakaria R. Antioxidant Activity of Dichloromethane Extract and Ginger Water (Zingiber officinale Roscoe) in Linoleic Acid. Jurnal Teknologi dan Industri Pangan; 2002; 13(2): 105-110.

19. Septianingrum NMAY, Haspari WS, and Amin MK. Formulation and Test for Effervescent Powder Extract Okra (Abelmosecus Esculeutus) as Nutridrink in Diabetes Patients. Media Farmasi; 2019; 16(1): 11-20.

20. Hamilton-Miller JMT, and Shah S. Activity of The Tea Component Epicatechin Gallate and Analogue Against Methicillin-Resistant Staphylococcus aureus. Journal of Antimicrobial Chemotherapy; 2000; 46: 847-863.

21. Molyneux P. The Use of The Stable Free Radical diphenylpicryl-hydrazyl (DPPH) for Estimating 
Antioxidant Activity. Songklanakarin. Journal Science Technology; 2004; 26(2): 211-219.

22. Hadiyanto H, Marsya MA, Fatkhiyatul, P. Improved Yield of Antioxidant Extraction $\beta$ Carotene from Microalgae Spirulina Plantesis Using Ultrasound Assistes Extraction. Jurnal Teknologi; 2015; 77(1): 219-222.

23. Pambayun R, Gardjito M, Sudarmadji S, and Kuswanto KR. Phenol Content and Antibacterial Properties on Various Types of Gambir Product Extracts (Uncaria gambir Roxb). Majalah Farmasi Indonesia; 2007; 18(3): 141-146.

24. Melechi. Optimization of The Sonication Extraction Method of Hibiscus tiliaceus
L.Fkowers. Ultrasonics Sonochemistry ; 2006; 13:242-250.

25. Mahmudah FL, and Atun S. Aantibacterial Activity Test of Ethanol Extract Temu Kunci (Boesenbergia pandurata) Againts Streptococcus mutans Bacteria. Jurnal Penelitian Saintek; 2017; 22(1): 59-66.

26. Kailaku SI, Sumangat J, Hernani. Effervescent Granule Formulation Rich in Antioxidants from Gambir Leaf Extract. Jurnal Pascapanen; 2012; 9(1): 27-34.

27. Dewandri KT, Yuliani S, and Yasni S. Extraction and Characterization of Red Betel Extract (Piper crocatum) Nanoparticles. Journal Pascapanen; 2013; 10(2): 58-65. 